\title{
ELDERLY TRAINING FOR USING DIGITAL TECHNOLOGIES: A LITERATURE REVIEW AND AN EMPIRICAL RESEARCH IN NORTH WESTERN ROMANIA
}

\author{
Dorin POPESCU ${ }^{a *}$, Diana PITIC ${ }^{b}$, Diana DRAGOMIR \\ ${ }^{a, c}$ T.U. Cluj-Napoca, Romania \\ ${ }^{b}$ Babes-Bolyai University, Cluj-Napoca, Romania
}

DOI: $10.24818 / \mathrm{IMC} / 2020 / 02.01$

\begin{abstract}
This paper addresses the issue of the use of general-purpose and assistive digital technologies by the elderly, able to make their lives easier and to reduce society's costs regarding their assistance. The focus is on training the elderly in order to use these technologies as follows: the role of initial formal education, barriers in use, attitude towards the idea of training, preferences on training methods, trainers, and the training process. The research uses an initial study of the literature that allows the identification of a first set of findings and the initial configuration of the survey for empirical research. The latter was conducted by direct or online interviews of the subjects based on a defined matrix questionnaire on domains and topics. The possibility of direct dialogue allowed the extension of the interview to a semi-structured form that brought additional information to the final conclusions. The low number of interviewed subjects is not likely to affect the relevance of the results, the research assumes from the beginning a qualitative approach and not one with statistical relevance.
\end{abstract}

KEYWORDS: Elderly using digital technologies, Elderly training, Elderly training characteristics

\section{INTRODUCTION}

The role of modern science has long passed from that of a simple investigator of reality to becoming, through knowledge, the main contributor to its creation and development, sometimes generating both its challenges and their related solutions. Scientific knowledge has significantly contributed to increasing both the standard of living and life expectancy on a global scale. Recent statistics of some world's key institutions such as the United Nations (UN, 2019), the World Bank (World Bank, 2019), the European Commission (Eurostat, 2019), the World Health Organization (WHO, 2018) etc. converge in highlighting the phenomenon of increasing life expectancy on a global scale. It is not the intention of this paper to summarize or analyze these figures, they are known and widely treated in the literature and on the web. It is considered important here to shed light on some of the consequences of the phenomenon which, although a positive one, in essence, raises serious challenges that require solutions, measures and actions both from science and on the line of social intervention. The need for solutions and interventions extends to all levels, from the technological and macrosocial on a global scale to the individual level of the elderly who need to be prepared and assisted to gain their wellbeing living independently and with reasonable social costs. The lack or inadequacy of such solutions and actions can turn the aging of the population into one of the great threats of the 21 st century to sustainable and inclusive development.

\footnotetext{
${ }^{*}$ Corresponding author. E-mail address: dorin.popescu@abstract.ro
} 
Technology could be a part of solutions to these challenges. The society's digital transformation and ICT evolutions such as Cyber-Physical Systems, Internet of Things, Smart Systems (smart cities, smart homes, smartphones, etc.) are now integrating rapidly in all segments of life: in economic activities, in mobility and transportation, in everyday life, at home, in contact with society's institutions (e.g. town hall, police, finance), in medical care, etc. The need for the digital transformation of the entire life of the planet, including or especially of the elderly has emerged more acute than ever during the Covid-19 pandemic. The requirements of social distancing with their consequences on the daily activities of the elderly forced in most situations to make purchases, pay bills, seek medical care, maintain the house, etc. without having or being able to use digital facilities telephone, computer, online commerce, e-banking, intelligent health monitoring systems, online medical consultations, etc., were a dramatic signal of "this is no longer possible". Solutions must be found and implemented to stop the "digital isolation" of the elderly, to make them compatible with and integrated into the modern world. Figures in European countries show that now more than ever, society needs to take effective action to reduce the root cause of digital exclusion: lack of knowledge and skills in operating related equipment and facilities required to access the mentioned services. In some Eastern European states, seniors' use of digital technologies is, even more, a critical issue, despite the existence of the necessary digital infrastructure. E.g. in Romania (Eurostat, 2020a) the percentage of households with broadband access is over $80 \%$ (in the Western region even $87 \%$ ), comparable or even surpassing developed regions from Western Europe. When observing people aged 65-74 and their use of digital facilities, the drop is spectacular. In 2017 almost $80 \%$ of this age group figure in the European statistics as never having used a computer, compared with less than $40 \%$ of the average EU28 and less than $20 \%$ in the bestplaced countries in this matter (Eurostat, 2019b). In 2019, in the mentioned country, only 7\% of people in the mentioned age group were counted as having at least basic digital skills, compared to $26 \%$ of the average EU28 and more than $50 \%$ in some Western European countries (Eurostat, $2020 \mathrm{~b}$ ). It is illustrative that only less than $4 \%$ of these people have made an Internet purchase until 2019 (Eurostat, 2020c). In this context, Romania has the lowest (7\%) rate of people 65-74 years old participating in education and training, comparing with the EU28 average of $16.7 \%$ and over 30\% of Denmark, Sweden, Finland or Switzerland (Eurostat, 2020d). If we look at the age group over 74 , the situation is considerably worse. As mentioned, the causes lay less on technical issues or even on peoples' financial situation or technology affordability but more on cultural ones, on the "normal" way of thinking and behaving. In the context set out above, and within the limits of the resources they were able to mobilize, the authors proposed in this paper to bring attention to the need and specific problems of training the elderly to acquire the skills needed to use current digital technologies, starting from those of general use (smartphone, computer, internet, media, ecommerce, and e-banking, etc.) and up to the specific assistive ones that are mainly addressed to them (smart wearables and e-health, or even more complex technologies of Ambient Assisted Living). After an extensive analysis of the literature meant to draw a conceptual framework of the approached topic, the research synthesizes an empirical study on a group of seniors from the urban environment in north-western Romania with different levels of previous formal education. The paper does not look at institutional interventions but at the individual response of older people to this challenge by asking to what extent they use digital technologies, what are their obstacles and restraints in this regard, how these could be addressed through training, on which pathways and ways this training could effectively address the needs of the elderly.

\section{RESEARCH METHODOLOGY}

The research steps are summarized in Table 1. The first phase has supposed the structuring of a conceptual framework that would then allow the pertinent design of the survey. The review of a considerable number of references led to the selection of 20 of them which were then analyzed to identify the main areas in which the training of the elderly has relevant implications. Of these, only 
those addressed directly to seniors were selected, social or institutional interventions not being the subject of this research. In this phase, the conceptual framework (subject areas) was also discussed with 2 trainers with experience in adult education to confirm they are the correct selection.

Concerning questionnaire design, the initial option was for a structured survey with some matrixtype sets of questions, each of these sets has an appropriate objective for the studied domain. Excepting the first one of these, focused on identifying the elderly use of digital technologies, each of the other domains contains questions related to key aspects/topics of the domain which can give an image of the relationship of the interviewed subject with these component issues. Within matrixes where the people's opinions were targeted, some of the key questions were repeated in a symmetrical formulation (the same issue being asked in two opposite ways: a positive and a negative perspective) to check the consistency of the answers. The check of the answers symmetry to these questions was done both at individual and at the entire survey level.

The subject's answers were placed on a Likert scale for each question.

Finally, the survey was conducted by directly interviewing the subjects, in this way opening the way to supplementary explanations (if they were asked) for each topic under discussion, as well as to the addressing of supplementary questions when it was considered useful for the survey's intention. In these conditions, even if the interview remained mainly a structured one, based on the established set of questions applied to all participants, the possibility existed to extend it with some supplementary questions when it was needed or opportune, thus turning its attributes toward a semistructured approach. For the confirmation and formulation of the final conclusions, a feedback was asked from specialists in adult education.

Table 1. Research methodology - research steps

\begin{tabular}{|c|c|c|c|c|}
\hline No & Inputs & Methods & Research steps actions and decisions & Results \\
\hline & \multicolumn{4}{|c|}{$\begin{array}{l}\text { Aim: To identify elders' attitudes towards the use of digital technologies, effective and efficient ways } \\
\text { of training older people to accept and use digital technologies that can make their lives easier. }\end{array}$} \\
\hline 1 & $\begin{array}{l}20 \text { selected } \\
\text { references }\end{array}$ & $\begin{array}{l}\diamond \text { Literature } \\
\text { review } \\
\diamond \text { Consultation } \\
\text { with specialists }\end{array}$ & $\begin{array}{l}\text { - Literature review for structuring a conceptual } \\
\text { framework for studying training elders in } \\
\text { using digital technologies } \\
\text { - Feedback from professionals in adult } \\
\text { education to confirm domains and topics } \\
\text { involved }\end{array}$ & $\begin{array}{l}\text { Set of specific } \\
\text { domains with } \\
\text { key topics on } \\
\text { each }\end{array}$ \\
\hline 2 & $\begin{array}{l}\text { Domains of } \\
\text { interest } \\
\text { Key topics } \\
\text { on each } \\
\text { domain }\end{array}$ & $\begin{array}{l}\diamond \text { Matrix type } \\
\text { survey/ } \\
\text { interview } \\
\diamond \text { Likert scale } \\
\text { evaluation }\end{array}$ & $\begin{array}{l}\text { - Define surveys' aim and objectives. } \\
\text { - Design of questioning matrices on domains } \\
\text { and on component topics and the Likert } \\
\text { Scale. } \\
\text { - Adding an open-ended question to each } \\
\text { matrix (Other-Which?) that allows the } \\
\text { answers extension to other topics. }\end{array}$ & $\begin{array}{l}\text { Survey/ } \\
\text { interview } \\
\text { structure } \\
\text { Questioning } \\
\text { matrices }\end{array}$ \\
\hline 3 & $\begin{array}{l}\text { Interviews } \\
\text { with } 3265+ \\
\text { persons in } \\
\text { two groups } \\
\text { with } \\
\text { different } \\
\text { education } \\
\text { levels }\end{array}$ & $\begin{array}{l}\diamond \text { Survey } \\
\diamond \text { Interview }\end{array}$ & $\begin{array}{l}\text { Interviewing elderly people on: } \\
\text { - their using of digital technologies (two } \\
\text { groups with equal number but different levels } \\
\text { of previous formal education); } \\
\text { - their attitudes and motivations, preferences } \\
\text { for ways of conducting, and specific process } \\
\text { aspects of training for gaining digital } \\
\text { competences. }\end{array}$ & $\begin{array}{l}\text { Collected } \\
\text { answers }\end{array}$ \\
\hline 4 & $\begin{array}{l}\text {-Elders' } \\
\text { answers } \\
\text {-Opinions } \\
\text { of } \\
\text { specialists }\end{array}$ & $\begin{array}{l}\diamond \text { Results } \\
\text { Analysis } \\
\diamond \text { Feedback from } \\
\text { trainers of adults }\end{array}$ & $\begin{array}{l}\text { - Seniors using digital technologies - analysis } \\
\text { of the dependence on the level of formal } \\
\text { education. } \\
\text { - Answers analysis and interpretation on } \\
\text { domains and topics, using also feedback from } \\
\text { specialists. }\end{array}$ & $\begin{array}{l}\text { Research } \\
\text { conclusions }\end{array}$ \\
\hline
\end{tabular}

Source: Established by authors 


\section{A LITERATURE REVIEW ON ELDERLY EDUCATION AND TRAINING}

"It is never too late to learn," said Confucius. Population aging, according to some authors, the reference phenomenon of the 21 st century, brings to public attention the need for institutional measures and solutions on a national and transnational scale to target the practices of aging ("active aging", "productive aging") and lifelong learning. (Schmidt-Hertha et al., 2014) predominantly give a European perspective on the need for older people education, emphasizing that, at the community level, authorities should take an explicit responsibility in planning, coordinating and financing the education of older people, taking over the role of regional learning hubs that bring together "providers (public, private and voluntary) to coordinate resources and promote learning among older people". (Findsen \& Formosa, 2016) extend the discussion on the education of the elderly to 42 states and regions of the world and (Lee, 2015) places it at the level of specific measures taken by a particular state, Taiwan where there is since 2006 an "Older Adult Education White Paper", emphasizing that education for the elderly must facilitate a self-sufficient, independent and active lifestyle. A general finding (Findsen \& Formosa, 2011) is that, sociologically, older people in formal education are a minority and not a socially favored one, in a context where society's resources for education are limited and government priorities do not favor the education of this age group.

In a world where digitalization has penetrated all segments of economic, social and private life, the lack of access of some segments of the population to ICT (Information and Communication Technologies), having as an implicit consequence their isolation from the community, including from those close to them, thus being equivalent to social exclusion (IGI Global, 2020), becomes a key dimension of inclusion in society and the community. People who cannot, do not know, or do not have the appropriate infrastructure to use the computer, smartphone, internet, web and media services, online commerce, banking or medical services, etc. are found in a considerably higher percentage among those with older ages, those with a precarious financial situation and a lower level of education (Burton, 2013).

The development of the knowledge and skills necessary to elders for using digital technologies in general and of those assistive ones can be achieved only through education-training processes. But are elders understanding this need, are they ready to accept the training, can the training of the elderly be just as effective under the same conditions, with the same providers and involves processes and facilitating factors similar to the training of young people and adults, or does it raise specific challenges and require different solutions? An immersion on this topic in the literature and on the web returns an impressive number of references related to the education of the elderly. Regarding the wealth of information identified on this subject, it should be noted here that it would be desirable for this popularity of the subject in the scientific world and information to find a stronger reflection in large-scale institutional interventions on the education of the elderly. Next, some of the relevant books and papers will be analyzed to find information to be used in the next step of the research undertaken in this paper.

Regarding the ability of older people to be trained, (Findsen \& Formosa, 2011), emphasizes that, from a psycho-cognitive point of view, it is difficult to indicate the distinct impact of a cognitive process affecting learning in old age, on the one hand because its effect cannot be isolated, and on the other hand, the boundary between "normality" and modified status at these ages is not always clearly delimited. It concludes that beyond the possible physiological and psychological constraints, people may have the ability to continue learning until extreme old age, with the elderly possessing a number of compensatory factors - such as the integrity of crystallized intelligence, accumulation of knowledge and experience, the persistence of curiosity and the ability to put new information in an extremely meaningful context - which could even give the elderly an advantage in this respect over the young. Related to cognitive processes and their changes in the elderly, (Findsen \& Formosa, 2011) highlights intelligence, attention, and memory, and as cognitive functions, language and 
problem solving, considering them all as complex concepts. Regarding each of them, the specialists claim that it has several components with different roots, definitions, and roles. Intelligence refers to "the limits of individual performance in performing intellectual tasks," attention being seen as "the ability to focus on something, despite distracting stimuli," and memory, "the ability to retain and reactivate what has been learned." Scales have been defined for the evaluation of intelligence (WAIS - "Wechsler Adult Intelligence Scale"), relative to which the influence of age on its components can be studied.

(Kececi \& Bulduk, 2012) on health education, confirm as myths and prejudices the supposition that the elderly have a poor capacity for understanding and learning or that they are unproductive, resistant to change, incapable and stereotyped, but note that they suffer from age degenerative changes that can affect the ability to learn. Some of these changes are:

- physical - impaired hearing, vision, ability to feel and respond, spatial orientation, mobility, and motor coordination;

- psychological - related to the person's ability to adapt to changes in perception and memory, learning and problem solving, psychological state and attitude, sense of self and personality;

- socio-cultural - are present on the background of the first ones and are referring to the increase of the need for independence as an expression of self-respect, education aiming at strengthening selfmanagement skills.

Special attention is paid in the literature (Findsen \& Formosa, 2011) to the learning process that presents particularities on the road "pedagogy-andragogy-geragogy". Some features of older learning include:

- The instructor-trainee relationship: at a young age, is of dependence: the instructor directs what, when, how to learn a subject, and tests what has been learned. At mature and advanced ages, the tendency is towards self-direction and independence, the instructor's task is to encourage and feed learning.

- The capitalizing of the experience is of low value to the children, in this case, the experience and the knowledge of the teacher and his teaching methods is prevailing. For mature and elderly students, the experience is a major resource that must be exploited, the teaching methodology being mainly focused on discussions and problem-solving.

- Willingness to learn: Children learn what society has established that they must learn, the curriculum is standardized. At mature ages and even more in the case of advanced ages, the trained people learn what they need to know and the training programs are organized around the specific targeted needs.

- Training orientation: For "school-children" what matters is learning the topics in the syllabus while for the mature and elderly people the focus is on using experience in achieving performance.

- Motivation: For school-children motivation has an extrinsic nature (parental pressure, fear of failure), for adults and the elderly, predominantly is intrinsic ones (self-esteem, usefulness, quality of life).

Although not very recent (Martha, 1988) is an intensely cited source that defines the principles of geragogy:

- Learning is oriented towards providing skills that maintain personal independence. To make sense for the elderly, the learning tasks' usefulness must be emphasized from the beginning.

- For elders a flexible and interdisciplinary approach based on teaching methods that meets their needs is preferable to one based on long verbal presentations.

- A clear focus on the topic must be maintained, limiting the number of presented ideas, avoiding irrelevant and distracting topics. 
- Concern for discipline should be replaced by close involvement, positive feedback, approval, and encouragement.

- Elders need repetitions and extensive use of examples for each learning task; this may ask for a longer time until they master it.

- The previous experience and knowledge must be reactivated; these being useful resources for elders in understanding and learning as well in stimulating their creativity.

As a synthesis of the studied literature, and for avoiding redundant exposition, the "Items" chosen to host the objectives and questions of the research are summarized in Table 2. These consist of 6 main areas related to the training of the elderly in the use of digital technologies. In each case the authors identified a number of key topics of discussion that would be relevant in that area. The table also indicates some identified bibliographic sources referring to the respective domains and topics.

Table 2. A conceptual framework for elderly training in the use of digital technologies

\begin{tabular}{|c|c|c|}
\hline Research areas & Key topics of research & References \\
\hline $\begin{array}{l}\text { 1. The extent of } \\
\text { using digital } \\
\text { technologies, } \\
\text { influence of their } \\
\text { level of formal } \\
\text { education }\end{array}$ & $\begin{array}{l}\text {-Usual technologies (smartphone, computer, internet, ...) } \\
\text {-Assistive monitoring technologies (smartwatch or smart- } \\
\text { wearables tracking pulse, movement, blood pressure, etc.) } \\
\text {-Online services (trade, banking, health, etc.), } \\
\text {-Other digitally programmable household technologies } \\
\text { (household robots, lighting systems, heat, security, etc.) }\end{array}$ & $\begin{array}{l}\text { (Eurostat, 2020) } \\
\text { (Eurostat, 2019a) } \\
\text { (Niehaves \& Plattfaut, } \\
\text { 2014), } \\
\text { (Anderson \& Perrin, } \\
\text { 2017) }\end{array}$ \\
\hline $\begin{array}{l}\text { 2. Reasons why } \\
\text { respondents are } \\
\text { reluctant to use } \\
\text { digital devices and } \\
\text { applications }\end{array}$ & $\begin{array}{l}\text {-Ignorance and fear of learning, } \\
\text {-Misunderstanding of the need and utility of such effort } \\
\text {-Distrust in own ability to learn } \\
\text {-Personal convenience and lack of desire to learn } \\
\text {-Fear of possible mistakes and their consequences. } \\
\text {-Fear of data security issues and possible financial losses }\end{array}$ & $\begin{array}{l}\text { (Vollmer, 2019), } \\
\text { (Ronning \& Sølvberg, } \\
\text { 2017), } \\
\text { (Anderson \& Perrin, } \\
\text { 2017), } \\
\text { (Leen, 2013) }\end{array}$ \\
\hline $\begin{array}{l}\text { 3. Attitudes towards } \\
\text { the idea of } \\
\text { learning the basics } \\
\text { of using digital } \\
\text { devices and } \\
\text { applications. }\end{array}$ & $\begin{array}{l}\text { Positive attitude; reasons for acceptance } \\
\text { - willingness and confidence in one's own ability to learn } \\
\text { - curiosity to find out what it is and how to do it to learn } \\
\text { Negative attitude; Reasons for rejection } \\
\text {-lack of interest and lack of self-confidence } \\
\text {-fear of ridicule in the opinion of others }\end{array}$ & $\begin{array}{l}\text { (Vaportzis, 2017), } \\
\text { (Findsen \& Formosa, } \\
\text { 2011), } \\
\text { (Ronning \& Sølvberg, } \\
\text { 2017), } \\
\text { (Leen, 2013) }\end{array}$ \\
\hline $\begin{array}{l}\text { 4. Preferences } \\
\text { regarding the } \\
\text { person who would } \\
\text { do the training }\end{array}$ & $\begin{array}{l}\text {-a professional trainer, } \\
\text {-a close relative or acquaintance, } \\
\text {-a person who is close in age, } \\
\text {-without a trainer, based on a TV program, online on the } \\
\text { computer, or on another external support). }\end{array}$ & $\begin{array}{l}\text { (Mitzner, 2008), } \\
\text { (Findsen \& Formosa, } \\
\text { 2011) }\end{array}$ \\
\hline $\begin{array}{l}\text { 5. Conditions } \\
\text { preferred by the } \\
\text { elderly for such } \\
\text { training }\end{array}$ & $\begin{array}{l}\text {-institutionally organization and participation, } \\
\text {-training existing on support and run when desired, } \\
\text {-home, occasionally having as trainer someone known, } \\
\text {-online training delivered by specialized organizations, } \\
\text {-online training on seniors' forums. }\end{array}$ & $\begin{array}{l}\text { (Mitzner, 2008), } \\
\text { (Findsen \& Formosa, } \\
\text { 2011), } \\
\text { (du Plessis et al., } \\
\text { 2011) }\end{array}$ \\
\hline $\begin{array}{l}6 \text { Aspects favoring } \\
\text { or disturbing } \\
\text { learning in the } \\
\text { training process }\end{array}$ & $\begin{array}{l}\text { Issues perceived as positive and negative regarding: } \\
\text {-concentrated duration and rhythm of the training, } \\
\text {-possibility to resume the meeting at another time, } \\
\text {-the repetition of the key aspects by the instructor, } \\
\text { - time for taking notes and interaction with the trainer } \\
\text {-the language used by the trainer } \\
\text {-preference for trainer demonstration or own learner } \\
\text { exercise in learning the operation on the digital device }\end{array}$ & $\begin{array}{l}\text { (Martha, 1988), } \\
\text { (Findsen \& Formosa, } \\
\text { 2011), } \\
\text { (Gómez, 2014), } \\
\text { (Leen, 2013), } \\
\text { (EasyTechSeniors, } \\
\text { 2020) }\end{array}$ \\
\hline
\end{tabular}

Source: authors according to mentioned sources 


\section{RESEARCH RESULTS AND DISCUSSION}

\subsection{Research carried out and their limits}

As already mentioned in the research methodology, the administration of the questionnaires was done mainly by a structured interview, questioning subjects face to face or in the virtual environment, in the second variant the process being usually assisted by relatives or close friends of the subjects who had experience in using a communication platform (Zoom, Teams, Skype, Google Meet).

This method was used after several attempts to complete the questionnaire unassisted, which showed the interviewees' needs for clarifications to answer in the channels intended by the questions. The authors have also taken into account the option of populating the survey with clarifications or extended wording to clarify in detail the intention of each question, but it would have determined a significant prolongation of its volume and, as a consequence, a decrease in the interviewees' willingness in devoting appropriate attention and responsibility.

Conducting the survey by interviewing each subject personally was at the same time both the main research advantage and the main cause of its limitations. The advantage comes from the possibility to clarify by supplementary remarks or added questions regarding each of the topics under attention, so the clearness of obtained information has gained a significant increase (having as a consequence also a certain extension of the interviews to a semi-structured approach). The limits were resulting from the small number of interviewed subjects and their placement exclusively in the urban environment. Difficult access in these conditions (Covid-19) to direct contact or online communication channeled the interviews to more or less known people (relatives, neighbors, close acquaintances, or people with whom the authors had common connections) which reduced the number of interviewees. Access to the rural environment was even more difficult, especially in the absence of relationships to facilitate eventual bridges to this environment.

Concerning the impact of the mentioned limits, the research proposed a qualitative approach, not targeting a statistical relevance of the results, the small number of interviewed subjects and the difficulties in acceding others, encumbered the possibility to have perfectly balanced numerical segments e.g. by sex and age. However, among the mentioned parameters, the present research only considered the differentiation in the previous formal education of the subjects (interviewees being part of two equal number groups "with" and "without" higher education) and this differentiation was taken in consideration just for the use of digital technologies by elderly. The sex of the respondents was completely ignored (considered as irrelevant for the purpose of the research). The age distribution of the respondents, even if it was recorded, was not counted as a differentiation element, this research not considering the need for educational interventions different by age segments among the over $65 \mathrm{~s}$. Therefore, we consider the obtained results as relevant for a qualitative approach, especially as empirical confirmations of important aspects and peculiarities of training the elderly on digital technologies previously identified in the literature. Regarding the presumption that the results are valid outside the urban cultural environment remains a hypothesis to research for the future.

\subsection{Research results and their interpretation}

The first survey matrix stands out from the others, focusing on the use of digital technologies by the respondents. In this case, a distinction was made between the group of those with a formal education equivalent to higher education and the others with lower levels of education, being followed by the hypothesis of an increased availability in the use of these technologies by the former. In this matter, the results of the 32 interviews can be found in Table 3 and confirm the respective hypothesis, proving (within the limits of a qualitative research) a greater openness of the elderly with higher education to accepting and using digital technologies. This dependence is not an 
exclusive one, seniors have been identified among the group lacking higher education who use these technologies.

Table 3. Elderly's using of digital technologies - on 2 levels of previous formal education

\begin{tabular}{|l|c|c|c|c|c|c|}
\hline & Not at all & $\begin{array}{c}\text { Only } \\
\text { assisted }\end{array}$ & $\begin{array}{c}\text { Very rarely } \\
\text { few times) }\end{array}$ & $\begin{array}{c}\text { Rare } \\
\text { (once a month) }\end{array}$ & $\begin{array}{c}\text { Quite often } \\
\text { once a week) }\end{array}$ & $\begin{array}{c}\text { Usually } \\
\text { (daily) }\end{array}$ \\
\hline Mobile phone & $5\left(1^{*}, 4\right)$ & 0 & 0 & 0 & $2\left(1^{*}, 1\right)$ & $25\left(14^{*}, 11\right)$ \\
\hline $\begin{array}{l}\text { Smartphone for: web connection, } \\
\text { digital devices control etc. }\end{array}$ & $18\left(6^{*}, 12\right)$ & $5\left(3^{*}, 2\right)$ & 0 & $1\left(1^{*}, 0\right)$ & $1\left(1^{*}, 0\right)$ & $7\left(5^{*}, 2\right)$ \\
\hline Computer/tablet & $17\left(6^{*}, 11\right)$ & $3\left(1^{*}, 2\right)$ & $3\left(1^{*}, 2\right)$ & $1\left(1^{*}, 0\right)$ & $1\left(1^{*}, 0\right)$ & $7\left(6^{*}, 1\right)$ \\
\hline Internet \& media & $18\left(7^{*}, 11\right)$ & $4\left(2^{*}, 2\right)$ & $3\left(1^{*}, 2\right)$ & 0 & $1\left(1^{*}, 0\right)$ & $6\left(5^{*}, 1\right)$ \\
\hline E-commerce & $21\left(7^{*}, 14\right)$ & $5\left(4^{*} 1\right)$ & $2\left(1^{*}, 1\right)$ & 0 & $4\left(4^{*}, 0\right)$ & 0 \\
\hline Online payments and banking & $25\left(10^{*}, 15\right)$ & $3\left(2^{*}, 1\right)$ & $2\left(2^{*}, 0\right)$ & $2\left(2^{*}, 0\right)$ & 0 & 0 \\
\hline Smart wearables (watch or others) & $28\left(13^{*}, 15\right)$ & 0 & 0 & 0 & 0 & $4\left(3^{*}, 1\right)$ \\
\hline Online medical services & $30\left(14^{*}, 16\right)$ & $1\left(1^{*}, 0\right)$ & $1\left(1^{*}, 0\right)$ & 0 & 0 & 0 \\
\hline Digital household equipment ** & $27\left(11^{*}, 16\right)$ & $2\left(1^{*}, 1\right)$ & 0 & $1\left(1^{*}, 0\right)$ & $2\left(2^{*}, 0\right)$ & 0 \\
\hline
\end{tabular}

* Previous formal education equivalent with higher education

** Security, heating \& ventilation, robot vacuum cleaner or similar

\section{Source: Synthesis of survey's feedbacks}

Other findings: even if the large majority of seniors accept and use their smartphone as a telephone on a daily basis, considerably less of them are capable of independently using its "smart" facilities which suppose connection to web, Wi-Fi, external smart devices and services. A similar situation is found regarding the use of computers/tablets. Only an extremely low number of seniors use facilities and functions that would bring them relief in their everyday life, such as internet and media for information and communication, online services such as banking, e-commerce or healthcare, digital control of household smart devices and functions.

The other survey matrixes were searching for elderly attitudes toward using technologies, towards training for getting the necessary basic competences, the preferred ways, training persons and options concerning the education process. The data was centralized as the number of answers on the Likert scale for each question generating a numeric field that could receive suggestive representations as exemplified in Figure 2. As mentioned before, for testing the reliability of the answers, symmetrical questions have been used for some key issues (e.g. in Figure 2 questions 2 and 5 respectively 3 and 4). Looking at the results, the answers have returned quite symmetrical also proving the fact that the subjects have given generally their full attention and responsibility to the survey.

Due to the low number of questioned subjects (for reaching a 95\% relevance at least 10 times more subjects would have been necessary), results have not been submitted to statistical processing but just to a qualitative analysis on two-levels: a general one, looking for the common conclusions, and a specific one applied to the answers given on each domain and topic in part. Both the general and specific interpretations and conclusions on the topics were then discussed with two specialists with experience in adult training, subsequently being given their final formulation.

As a first general remarque, the results of the empirical investigation are converging with the previous findings in the literature on the pursued dimensions about training elderly for the use of general and assistive digital technologies: the measure to which they use such technologies, their understanding of the need, their willingness to learn, ways of accomplishing the instruction, aspects of the training process.

A second general finding is that the vast majority of respondents give importance to the idea of using digital technologies and even if they are reluctant to do so, they are denied neither their usefulness nor their growing emergence in everyday life. 


\section{I am willing to learn if I am convinced that it} is necessary and useful

2. It's an effort I feel able to make

3. I would like to know: what, how, where I can learn and how long it would take.

4. I'm not interested in the problem

5. It's an effort I'm not able to make at my age

6. I am embarrassed by what others will think of me in this matter

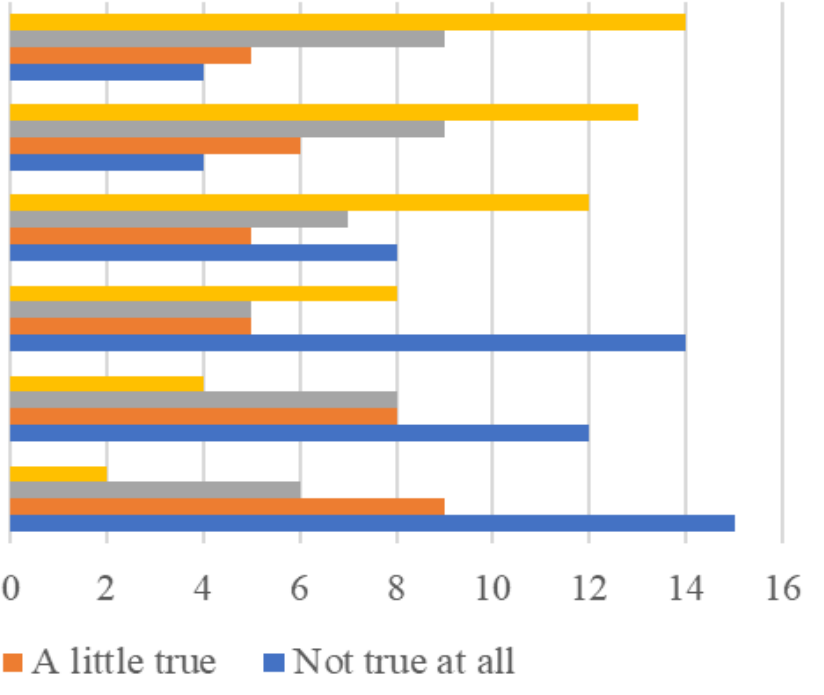

Figure 1. Survey results on attitudes towards the idea of learning to use digital technologies Source: Data from performed survey/interviews

Another general finding is related to a certain polarization of the position both towards digital technologies in general and regarding the training related to their use. There is no uniform distribution of opinions but a concentration of them towards the two ends: "I use computer frequently or not at all", "It is fully true or fully false that I have to learn to use computers, or I am capable to do that". Only a few answers are placed in the middle, the subjects positioning themselves there, more out of prudence and insufficient knowledge than because of an indifferent opinion such as "for me, it can be either way".

The specific findings on each of the objectives and questions of the survey are recorded in Table 4. Knowing and understanding the elderly needs, limits, and preferences in the way they approach learning, opens a future possibility of designing their training programs based on "requirement oriented development" or "competitive development" tools (e.g. QFD) as presented in other publications such (Popescu et al., 2019), (Opruta et al., 2008) and (Popescu et al., 2012).

Table 4. Some key conclusions specific to each area investigated in the survey

\begin{tabular}{|c|c|}
\hline Area & Specific conclusions \\
\hline 1.The use of digital technology & $\begin{array}{l}\text { Most respondents use smartphones as a mobile device to } \\
\text { communicate with loved ones. There are very few elderly people } \\
\text { who use their devices' smart functions (personal planning, web } \\
\text { connection, control of smart household devices, personal fitness } \\
\text { monitoring, etc.). The use of computers, the Internet, media } \\
\text { communication facilities, or their online functions as banking, e- } \\
\text { commerce, medical assistance is common to a relatively small } \\
\text { number of older people. The use of smart devices and facilities } \\
\text { assisted by computer or with digital programming is an } \\
\text { exception in this age group. If it occurs, it happens with the } \\
\text { assistance of relatives or qualified persons. }\end{array}$ \\
\hline 2.Barriers in using digital technologies & $\begin{array}{l}\text { With the exception of the "fear of error and its consequence', } \\
\text { there was no main reservation on the use of digital technologies, } \\
\text { thus most of the respondents adopted a position of "I can do } \\
\text { what I have to do without them" Cybersecurity risks are } \\
\text { understood only by very few users but contribute to their fear of } \\
\text { the danger of financial loss or even personal security. }\end{array}$ \\
\hline
\end{tabular}




\begin{tabular}{|c|c|}
\hline Area & Specific conclusions \\
\hline $\begin{array}{l}\text { 3.Willingness to learn how to use } \\
\text { digital technologies }\end{array}$ & $\begin{array}{l}\text { The attitude of those questioned towards the idea of being } \\
\text { trained in the use of digital technologies is mostly positive. } \\
\text { There is a disposition to make an effort to learn, doubled by a } \\
\text { certain fear related to the limits of personal physical and } \\
\text { intellectual capacity in the success of this approach. It is } \\
\text { noteworthy that quite a low sensitivity to the negative opinions } \\
\text { of others was found (there is no fear of ridicule in this regard), } \\
\text { while similar questions about the influence coming from the } \\
\text { positive example of close people highlight their strong impact. }\end{array}$ \\
\hline 4.Preferences on "with whom to learn" & $\begin{array}{l}\text { Regarding the trainers, there is a significant desire to work with } \\
\text { professionals but even more, the preference is directed to } \\
\text { relatives as well as to known people close in age. At least in } \\
\text { Romania, at this moment and in the sample in question, the idea } \\
\text { of online forums for the elderly where they can learn from each } \\
\text { other is not widespread. }\end{array}$ \\
\hline $\begin{array}{l}\text { 5.Preferences on "in which way to } \\
\text { learn" }\end{array}$ & $\begin{array}{l}\text { Regarding the ways/conditions in which it would be preferable } \\
\text { for the training to take place, it should be noted that, at this } \\
\text { moment and in this age category, the online training, on } \\
\text { specialized sites or forums, those of the tv-school type or on } \\
\text { external support (ex. DVD, memory) are not popular. The } \\
\text { interviewed subjects prefer institutionalized training (planned } \\
\text { day, time, objectives, duration, etc.) with a physical presence, at } \\
\text { home, or in "school" type spaces. }\end{array}$ \\
\hline 6.Preferences on "how to learn" & $\begin{array}{l}\text { Regarding the training process, the results of the questionnaire } \\
\text { mostly confirm the particularities identified in the literature. For } \\
\text { the elderly the following aspects are important: an accessible } \\
\text { rhythm of teaching, the repetition of key aspects, the possibility } \\
\text { to take notes, the use of a familiar language, the possibility to } \\
\text { practice personally what is to be done, and the interactivity of } \\
\text { teaching. }\end{array}$ \\
\hline
\end{tabular}

Source: Established by the authors

\section{CONCLUSIONS}

In the digital age, the ignorance and inability of the elderly to use modern technologies is a more serious handicap than physical ones. It leads to their social exclusion and significantly increases the costs of society to ensure their wellbeing and independence at a reasonable cost. In this sense, supporting the elderly to accept, learn, and use digital technologies is becoming a key priority of today's society.

Beyond the limitations that come with the attenuation of senses such as hearing and sight, mobility, and the cognitive function of memory, in the absence of pathologies that severely affect cognitive functions, the elderly can and are willing to learn. Moreover, their experience can help them compensate for the mentioned attenuations and increase the effectiveness of learning.

There is a significant correlation between openness to the use of digital technologies in old age and the level of formal education of subjects, but it should be noted that a more modest initial education is not a real obstacle to the training or use of digital technologies. A clear explanation of the need and utility for their life and the example of those around give a positive dynamic in adopting digital technologies even among the elderly with a low-level initial education.

At least in Romania, a reluctance to use online training, still exists among elders. They prefer faceto-face training with competent but, when possible, known trainers with similar ages to them. In the 
training process, it is important to maintain an accessible rhythm, the possibility to retain and resume what has been learned, the interactivity with the trainer and possibly the others who are learning, and the possibility to practice what has been learned.

\section{REFERENCES}

Anderson, M., \& Perrin, A. (2017). 1. Technology use among seniors and 2. Barriers to adoption and attitudes towards technology. Retrieved on Oct $15^{\text {th }}$ from Pew Research Center: https:/www.pewresearch.org/internet/2017/05/17/technology-use-among-seniors/

Burton, L. (2013). Low income and digital exclusion. Retrieved on Oct $15^{\text {th }}$ from Powerty and Social Exclusion: https://www.poverty.ac.uk/editorial/low-income-and-digital-exclusion

du Plessis, K., Anstey, K., \& Schlumpp, A. (2011). Older adults' training courses: Considerations for course design and the development of learning materials. Australian Journal of Adult Learning, Vol.51, No. 1, 161-174.

EasyTechSeniors. (2020). Ultimate Guide to Teach Tech to Seniors in 2020. Retrieved from EasyTechSeniors: https://easytechseniors.com/ultimate-guide-to-teach-tech-to-seniors-2/

Eurostat. (2019). Ageing Europe 2019 Edition. Luxembourg: Publications Office of the European Union.

Eurostat. (2019a). Education and digital society among older people. Retrieved on Oct $16^{\text {th }}$ from Eurostat: $\quad$ https://ec.europa.eu/eurostat/statistics-explained/index.php?title=Ageing Europe_statistics_on_social_life_and_opinions\#Education_and_digital_society_among_ol der people

Eurostat. (2019b). People never having used a computer, by age class, 2008 and 2017 (\%). Retrieved on Oct $15^{\text {th }}$ from Eurostat: https://ec.europa.eu/eurostat/statisticsexplained/index.php?title=File:People_never_having_used_a_computer,_by_age_class,_20 08_and_2017_(\%25)_AE2019.png

Eurostat. (2020). Digital Economy and Society. Retrieved on Oct $17^{\text {th }}$ from European Comission Eurostat: https://ec.europa.eu/eurostat/web/digital-economy-and-society/data/database

Eurostat. (2020a). Households with broadband access. Retrieved on Oct $16^{\text {th }}$ from Eurostat: https://appsso.eurostat.ec.europa.eu/nui/show.do?dataset=isoc_r_broad_h\&lang=en

Eurostat. (2020b). Individuals' level of digital skills. Retrieved on Oct $\overline{1}^{\text {th }}$ from Eurostat: https://appsso.eurostat.ec.europa.eu/nui/submitViewTableAction.do

Eurostat. (2020c). Internet purchases by individuals (until 2019). Retrieved on Oct $1^{\text {st }}$ from Eurostat: https://appsso.eurostat.ec.europa.eu/nui/submitViewTableAction.do

Eurostat. (2020d). Participation rate in education and training (last 4 weeks) by sex and age. Retrieved from

Eurostat: https://appsso.eurostat.ec.europa.eu/nui/submitViewTableAction.do

Findsen, B., \& Formosa, M. (2011). Lifelong learning in later life: A handbook on older adult learning. Rotterdam: Sense Publishers.

Findsen, B., \& Formosa, M. (2016). International Perspectives on Older Adult Education, Research, Policies and Practice. Springer.

Gómez, R. (2014). Older adult FL learning: Instructors' beliefs and some recommendations . In N. Sonda \& A. Krause (Eds.), JALT2013 Conference Proceedings (pp. 229-239). Tokyo: JALT.

IGI Global. (2020). What is Digital Exclusion. Retrieved on Oct $5^{\text {th }}$ from IGI Global: https://www.igi-global.com/dictionary/digital-exclusion/7615 
Kececi, A., \& Bulduk, S. (2012). Health Education for the Elderly, Chapter 11 in book. Geriatrics (p. Cap.11). DOI:10.5772/33472.

Lee, Y. (2015). Older adult education: new public pedagogy in 21st century Taiwan. Australian Journal of Adult Learning, Volume 55, Number 3, 460-476.

Leen, E. (2013). Motivation in ICT Learning in Older Adults: Dimensions of Learning Motivation, Influencing Factors and Implications for ICT Course Concepts. Erlangen-Nuremberg: PhD Thesis - Friedrich-Alexander-Universität Erlangen-Nuremberg.

Martha, J. A. (1988). Geragogy: A Theory for Teaching the Elderly. Routledge.

Mitzner, T. L. (2008). Older Adults' Training Preferences for Learning to Use Technology. Proc Hum Factors Ergon Soc Annu Meet. 2008 Sep; 52(26): 2047-2051. doi: $10.1177 / 154193120805202603$.

Niehaves, B., \& Plattfaut, R. (2014). Internet adoption by the elderly: employing IS technology acceptance theories for understanding the age-related digital divide. European Journal of Information Systems volume 23, 708-726.

Opruta, D.; Dragan, M.; Dragomir, M. (2008). Method of competitive development applied in the orientation towards the market requirements of a study program. 5th International Seminar on Quality Management in Higher Education Location: Tulcea, ROMANIA, JUN 12-14, 2008, Pages: 565-570.

Popescu, S.; Dragomir, M.; Pitic, D.; Brad, E. (2012), Method for competitive environmental planning, Environmental Engineering and Management Journal, DOI: 10.30638/EEMJ.2012.105

Popescu S., Rusu D., Dragomir M., Popescu D., Nedelcu Ș. (2019). Competitive Development Tools in Identifying Efficient Educational Interventions for Improving Pro-Environmental and Recycling Behavior. International Journal of Environmental Research and Public Health, 17(1):156, 10.3390/ijerph17010156.

Ronning, W. M., \& Sølvberg, A. M. (2017). Older Adults' Coping with the Digital Everyday Life. Seminar.net Vol.13, No 2, Retrieved on Oct $10^{\text {th }}$ from https://journals.hioa.no/index.php/seminar/article/view/2307.

Schmidt-Hertha, B., Krašovec, S. J., \& Formosa, M. (2014). Learning across Generations in Europe, Contemporary Issues in Older Adult Education. ROTTERDAM / BOSTON / TAIPEI: SENSE PUBLISHERS.

UN. (2019). World Population Prospects 2019, Highlights. New York: United Nations, Department of Economic and Social Affairs.

Vaportzis, E. e. (2017). Older Adults Perceptions of Technology and Barriers to Interacting with Tablet Computers: A Focus Group Study. Frontiers in Psychology.

Vollmer, D. e. (2019). The Conversation. Retrieved from How technology could be a solution to caregiver shortage for seniors: https://theconversation.com/how-technology-could-be-asolution-to-caregiver-shortage-for-seniors-103878

WHO. (2018). Ageing and health. Retrieved from World Health Organization: https://www.who.int/news-room/fact-sheets/detail/ageing-and-health

World Bank. (2019). Population ages 65 and above (\% of total population). Retrieved on Oct $15^{\text {th }}$ from The World Bank: https://data.worldbank.org/indicator/SP.POP.65UP.TO.ZS 